Scientific paper

\title{
Simple and Sensitive High Performance Liquid Chromatography Method with Fluorescence Detection for Therapeutic Drug Monitoring of Topiramate
}

\author{
Daniela Milosheska, Tomaž Vovk, Iztok Grabnar and Robert Roškar* \\ University of Ljubljana, Faculty of Pharmacy, Aškerčeva cesta 7, 1000 Ljubljana, Slovenia \\ * Corresponding author: E-mail: robert.roskar@ffa.uni-lj.si \\ Tel: +38614769 655, Fax: +38614258031
}

Received: 28-02-2014

\begin{abstract}
A simple, sensitive, reliable, inexpensive and reproducible HPLC method with fluorescence detection, suitable for routine therapeutic drug monitoring (TDM) of an antiepileptic drug topiramate, was developed and validated. The determination of plasma topiramate concentration was carried out after precolumn derivatization, using 4-chloro-7-nitrobenzofurazan as a fluorescent labeling agent and bendroflumethiazide as an internal standard. The standard calibration curve was linear over the concentration range of $0.01-24 \mu \mathrm{g} / \mathrm{mL}\left(\mathrm{r}^{2}>0.9998\right)$. The intra- and inter-day accuracies expressed as bias were from 1.4 to $9.9 \%$ and from 1.9 to $10.2 \%$, respectively. The intra- and inter-day precisions were below $7.9 \%$ and $2.7 \%$, respectively. The validated method was applied for the measurement of plasma topiramate concentrations in patients with epilepsy. The reported method is appropriate for TDM of topiramate as well as for pharmacokinetic and bioequivalence studies.
\end{abstract}

Keywords: Topiramate, HPLC with fluorescence detection, derivatization agent, human plasma, therapeutic drug monitoring

\section{Introduction}

Topiramate (TPM, 2,3:4,5-Bis-O-(1-methylethylidene)- $\beta$-D-fructopyranose sulfamate, Figure 1A) is a broad-spectrum second-generation antiepileptic drug (AED), approved as a mono or as an adjunctive therapy in adult and pediatric patients. ${ }^{1-3}$ Structurally it is unrelated to other classes of antiepileptic drugs. TPM is a derivative of the naturally occurring monosaccharide D-fructose with a sulfamate group, which is essential for its anticonvulsant activity. It is a weak acid $(\mathrm{pKa}=8.7)$ and in spite of the relatively low lipophilicity $(\log \mathrm{P} \approx 0.5)$ passes the blood-brain barrier. ${ }^{4}$ Compared to the first generation of AEDs TPM pharmacokinetics is more predictable. After oral administration it is rapidly and almost completely absorbed. Within the therapeutic dose range the relationship between dose and serum concentration is linear. The reported reference range of effective serum concentration is $5-20 \mu \mathrm{g} / \mathrm{mL} .^{5}$ TPM is predominantly $(70 \%)$ excreted unchanged in urine with an elimination half-life of 20-30 h., ${ }^{2,5}$ Nevertheless, with concomitant ad- ministration of enzyme-inducing AEDs, such as phenytoin, carbamazepine or phenobarbital, hepatic metabolism of TPM becomes more important and can result in up to two-fold increase in oral clearance of TPM with a correspondingly decreased elimination half-life $(10-12 \mathrm{~h}){ }^{5-9}$ Still, TPM remains considerably excreted unchanged in urine $(40 \%)$. Despite extensive knowledge of the fundamental metabolic processes, to date, there is sparse quantitative information on TPM metabolic fate because of the difficulties to assay all possible metabolites. ${ }^{7}$ 2,3-O-desisopropylidene topiramate and 10-hydroxy topiramate are the most abundant urinary metabolites. ${ }^{7,8}$

On the other hand TPM clearance can be decreased, if co-administered with valproic acid, propranolol, lithium, amitriptyline or sumatriptan. ${ }^{5,7}$ Additionally, due to higher clearance rate and larger volume of distribution, children and infants require higher doses $(\mathrm{mg} / \mathrm{kg})$ to achieve similar TPM plasma levels to those observed in adults. ${ }^{1,10,11}$

Drug interactions and individual factors such as age and renal function can markedly affect TPM concentra- 
tion, suggesting that there is some room for improvement in its clinical use. ${ }^{6,12}$ Therapeutic drug monitoring (TDM) may be useful in dose optimization on the initially prescribed treatment, in ascertaining drug compliance, in attributing toxicity to drug treatment, and in managing overdoses and drug-drug interactions. Nevertheless, the value of TDM of TPM has not been established due to lack of documented correlation between serum concentration and drug effects. $5,6,13,14$

The availability of a simple, validated and inexpensive analytical method for reliable measurements of drug concentrations in biological fluids is pivotal for its successful utilization in pharmacokinetic and bioequivalence studies, and for therapeutic drug monitoring in various clinical situations. ${ }^{15}$ Various analytical methods have been reported for measurement of TPM in biological fluids, including immunoassays, ${ }^{16,17}$ gas chromatography (GC) coupled to flame ionization detection (FID) ${ }^{18}$ or nitrogen phosphorous detection (NPD), ${ }^{19-22}$ high performance liquid chromatography with UV (HPLC-UV) ${ }^{23}$ or fluorescence detection (HPLC-FLD), ${ }^{24-26}$ capillary electrophoresis with UV detection, ${ }^{27}$ liquid chromatography coupled to mass spectrometry (LC-MS), ${ }^{28,29}$ and more recently, liquid chromatography coupled to tandem mass spectrometry (LC-MS/MS). ${ }^{12,30-36}$

The analysis of TPM in biological fluids is complicated, because like most other carbohydrates and their derivatives, TPM does not contain any chromophores that absorb above $190 \mathrm{~nm}$. Consequently, TPM has extremely low UV-visible absorbance and no spontaneous fluorescence, and cannot be directly analyzed by conventional HPLC with UV or fluorescence detection. GC separation on a capillary column with FID or NPD, and fluorescence polarization immunoassay (FPIA) were the first reported methods for the determination of TPM. ${ }^{37}$ However, due to thermolability TPM is poorly suited for GC analysis. The reported limits of quantification (LOQ) with various GC techniques were $0.5-2.5 \mu \mathrm{g} / \mathrm{mL} .^{18-21}$ FPIA is commonly used in routine TDM. With a stated analytical range of $2-32 \mu \mathrm{g} / \mathrm{mL}$ it has sufficient precision and accuracy but may be prone to interference from TPM metabolites. ${ }^{16,30}$ Recently, a new immunoassay for determination of TPM in serum, with considerably wider analytical range $(1.5-54.0 \mu \mathrm{g} / \mathrm{mL})$ than FPIA immunoassay, has become available. Although, this immunoassay performed comparably to FPIA, there are concerns about overall performance at high and very low TPM concentrations even within the stated analytical range. ${ }^{17}$

Lately, analyses of TPM in human serum following precolumn derivatization with fluorescent reagent 9-fluorenylmethyl chloroformate have been reported using fluorescence ${ }^{24}$ or $\mathrm{UV}^{23}$ detection. Another method by the same authors adopts 4-chloro-7-nitrobenzofurazan (NBD$\mathrm{Cl}$ ) as a fluorescent labeling agent, which enables the determination of TPM at concentrations down to 0.01 $\mu \mathrm{g} / \mathrm{mL} .{ }^{25}$ These methods have been validated over the concentration range of 0.02 to $5 \mu \mathrm{g} / \mathrm{mL}^{24} 0.04$ to 40 $\mu \mathrm{g} / \mathrm{mL}^{23}$ and 0.01 to $12.8 \mu \mathrm{g} / \mathrm{mL}^{25}$ Furthermore, HPLCFLD method using dansyl chloride for derivatization was recently proposed for simultaneous determination of TPM, vigabatrin and gabapentin, with a linearity range of $1-50 \mu \mathrm{g} / \mathrm{mL}$ for TPM. ${ }^{26}$

For ionizable analytes capillary electrophoresis could be an alternative to HPLC. Recently, a rapid capillary zone electrophoresis method with indirect UV detection for determination of TPM in human plasma with a linearity range $2-60 \mu \mathrm{g} / \mathrm{mL}$ was developed and validated. ${ }^{27}$

For selective, sensitive and fast determination of TPM, also avoiding the derivatization step, LC-MS or LC-MS/MS have become the preferred choice. Analytical ranges of these methods developed for TDM were 1-20 $\mu \mathrm{g} / \mathrm{mL},{ }^{28} 1-30 \mu \mathrm{g} / \mathrm{mL},{ }^{29} 0.8-40 \mu \mathrm{g} / \mathrm{mL},{ }^{31} 0.5-30 \mu \mathrm{g} / \mathrm{mL},{ }^{12}$ $0.02-20 \mu \mathrm{g} / \mathrm{mL}^{30}$ and $2.1-52.5 \mu \mathrm{g} / \mathrm{mL}^{35}$ while for pharmacokinetic and bioequivalence studies analytical ranges were $0.01-2 \mu \mathrm{g} / \mathrm{mL}^{33,36} 0.01-4 \mu \mathrm{g} / \mathrm{mL}^{32}$ and $0.02-5$ $\mu \mathrm{g} / \mathrm{mL} .{ }^{34}$ However, this instrumentation is expensive, requires highly trained personnel and is not available in every laboratory. Due to their availability and capability of high throughput, conventional HPLC methods for newer AEDs have been of continuous interest.

The objective of the present report was to develop and validate a simple, sensitive, reliable, inexpensive and reproducible HPLC-FLD method for routine application in TDM of TPM. The present method has two main advantages compared to the previously developed HPLC-FLD methods with precolumn derivatization for the analysis of TPM in human serum or plasma. Namely, in our method we use less organic solvents and smaller plasma volumes and achieve comparable sensitivity to the LC-MS methods and wider analytical range. The analytical range of the present method completely covers the proposed reference range and the method can be used for TDM as well as for pharmacokinetic and bioequivalence studies. The suitability of the method for TDM was demonstrated by measuring TPM in plasma samples of patients with epilepsy.

\section{Experimental}

\section{1. Chemicals and Reagents}

TPM was obtained from Sequoia Research Products (Pangbourne, UK), while bendroflumethiazide as an internal standard (IS) and 4-Chloro-7-nitrobenzofurazan (NBD-Cl) as a derivatization reagent were obtained from Sigma Aldrich (Steinheim, Germany). HPLC grade methanol and acetonitrile were purchased from Sigma Aldrich (Steinheim, Germany). All other chemicals used, including dichloromethane, diethyl ether, ethyl acetate, hexane, boric acid, potassium dihydrogen phosphate, sodium hydroxide and formic acid all from Merck (Darmstadt, Germany) were at least analytical grade. Water for 
all applications was obtained from a Q-POD Milli-Q water purification system (Millipore Corp., Billerica, USA) with resistivity $\geq 18.2 \mathrm{M} \Omega \mathrm{cm}$.

\section{2. Instrumentation and Chromatographic Conditions}

The chromatographic analysis was carried out on Agilent 1100 series HPLC system (Waldbronn, Germany) equipped with vacuum degasser, binary pump, autosampler, thermostat, fluorescence detector and ChemStation for data handling. Separation was performed on a reversed-phase column Eclipse plus C18 $(150 \times 4.6 \mathrm{~mm}, 5 \mu \mathrm{m}$; Agilent technologies, Palo Alto, USA) coupled to the $\mathrm{C} 18$ $(4.0 \times 3.0 \mathrm{~mm})$ guard precolumn (Phenomenex, Torrance, USA), using isocratic elution with potassium phosphate buffer (0.05 M; pH 5.5) and acetonitrile (98\%), (61.5: $38.5, \mathrm{v} / \mathrm{v})$ as a mobile phase, at a flow rate of $1.5 \mathrm{~mL} / \mathrm{min}$. Prior to use, the mobile phase was filtered through a 0.45 $\mu \mathrm{m}$ filter under vacuum and ultrasonically degassed. The column temperature was kept at $45{ }^{\circ} \mathrm{C}$ and the autosampler temperature at $4{ }^{\circ} \mathrm{C}$. A sample volume of $15 \mu \mathrm{L}$ was injected and TPM and IS were detected with the fluorescence detector set at excitation and emission wavelengths of 475 and $530 \mathrm{~nm}$, respectively.

\section{3. Preparation of Solutions}

Stock solutions of TPM $(5 \mathrm{mg} / \mathrm{mL})$ and IS $(0.5$ $\mathrm{mg} / \mathrm{mL}$ ) were prepared by dissolving appropriate amounts in water and methanol, respectively. Working solutions of TPM were prepared fresh daily from stock solution by further dilution with water. A borate buffer $(0.5 \mathrm{M})$ was prepared by dissolving boric acid in water and adjusted to pH 10.5 with $0.1 \mathrm{M}$ sodium hydroxide solution. A 6 $\mathrm{mg} / \mathrm{mL}$ solution of NBD-Cl in a mixture of methanol-acetonitrile $(1: 1, \mathrm{v} / \mathrm{v})$ was prepared daily. All solutions were stored at $4{ }^{\circ} \mathrm{C}$.

\section{4. Sample Preparation and Derivatization}

Into $2 \mathrm{ml}$ polypropylene tubes, $500 \mu \mathrm{L}$ plasma sample, $25 \mu \mathrm{L}$ of IS stock solution and $25 \mu \mathrm{L}$ of water were added. Samples were acidified to $\mathrm{pH} 6.0$ with $20 \mu \mathrm{l}$ of $2 \%$ aqueous solution of formic acid and mixed for $30 \mathrm{~s}$ on a vortex mixer. After addition of $1.5 \mathrm{~mL}$ dichloromethane, samples were again vortexed for $1 \mathrm{~min}$ and centrifuged at $2300 \times \mathrm{g}$ for $10 \mathrm{~min}$ at $5^{\circ} \mathrm{C}$. $1.2 \mathrm{~mL}$ of the organic phase was removed and evaporated to dryness under a stream of nitrogen at $50{ }^{\circ} \mathrm{C}$ (Turbovap LV, Caliper, Hopkinton-MA, USA). To the dry residue, $50 \mu \mathrm{L}$ of the NBD-Cl solution $(6 \mathrm{mg} / \mathrm{mL}), 50 \mu \mathrm{L}$ mixture of methanol-acetonitrile $(1: 1$, $\mathrm{v} / \mathrm{v})$ and $12.5 \mu \mathrm{L}$ of borate buffer $0.5 \mathrm{M}(\mathrm{pH} 10.5)$ were added. After mixing for $30 \mathrm{~s}$ the samples were kept on water bath at $60{ }^{\circ} \mathrm{C}$ for $15 \mathrm{~min}$. Derivatized samples were centrifuged at $16100 \times \mathrm{g}$ for $3 \mathrm{~min}$ at $5^{\circ} \mathrm{C}$. NBD-Cl deri- vatives were then transferred to vials with inserts and analyzed by HPLC-FLD.

\section{5. Method Validation}

The method was validated according to the US FDA guideline. ${ }^{38}$ Validation was performed on 3 separate days, each day including 12 calibration standards and five replicates of the quality control (QC) samples at three concentration levels.

Method selectivity was assessed by comparison of the chromatograms of drug-free plasma (blank plasma) from six different sources with those obtained from plasma samples spiked with TPM and IS. Additionally, several drugs that are potentially co-administered with TPM were tested to check for possible interferences at the retention time of the analytes.

Calibration standards were prepared by spiking drug free plasma with TPM at 12 plasma concentrations in the range of $0.01-24 \mu \mathrm{g} / \mathrm{mL}$. $25 \mu \mathrm{L}$ of TPM working solutions, $25 \mu \mathrm{L}$ of IS solution $(0.5 \mathrm{mg} / \mathrm{mL})$, and $20 \mu \mathrm{L}$ formic acid $(2 \%)$ were added to $500 \mu \mathrm{L}$ of blank plasma. The resulting plasma concentrations were: $0.01,0.03,0.06,0.12$, $0.3,0.6,1.2,3.0,12.0,18.0,21.0$ and $24.0 \mu \mathrm{g} / \mathrm{mL}$. Calibration standards were subjected to the extraction and derivatization procedure, and chromatographic analysis. The lowest limit of quantification (LLOQ) was calculated on the basis of the lowest concentration of TPM that gives coefficient of variation $(\mathrm{CV})$ and bias values $\leq 20 \%$. A weighted linear regression analysis was applied to calculate slopes, intercepts and determination coefficients of the calibration curves constructed as the peak area ratio of TPM to IS versus the TPM concentration, using $1 / \mathrm{x}^{2}$ as a weighting factor.

Accuracy and precision were assessed using quality control (QC) samples at concentrations of $0.03 \mu \mathrm{g} / \mathrm{mL}$ (QCl), $1.5 \mu \mathrm{g} / \mathrm{mL}(\mathrm{QCm})$ and $15 \mu \mathrm{g} / \mathrm{mL}$ (QCh); covering low, medium and high ranges of the calibration standards. Intra-day accuracy and precision were determined for five samples per concentration level at low, medium and high QC samples in a single run. Inter-day accuracy and precision were assessed by five determinations per concentration at low, medium and high QC samples from three runs analyzed on three different days. The intraand inter-day precision and accuracy of the assay were determined as percent coefficient of variation $(\mathrm{CV}(\%)=$ $($ standard deviation/mean $) \times 100)$ and percent bias values (bias $(\%)=[($ cal conc. - theo. conc. $) /$ theo. conc. $] \times 100)$, respectively. Acceptance criteria for accuracy and precision were the CV lower than $15 \%$, and the bias within \pm $15 \%$, except at LLOQ where it should not deviate by more than $\pm 20 \%$.

Extraction efficiency of the analytical method was determined for the analyte and IS. The mean extraction efficiencies were determined by measuring the peak area response of spiked (extracted) QC samples (QCl, QCm 
and QCh) against the peak area response of aqueous (unextracted) QC samples of the same concentration.

Stability was assessed by comparing the data of samples analyzed at time zero and after being exposed to the conditions for stability assessment. The freeze and thaw, short-term, long-term, stock solution and post-preparative stabilities of TPM in human plasma were investigated using three replicates of low $(0.03 \mu \mathrm{g} / \mathrm{mL})$ and high (15 $\mu \mathrm{g} / \mathrm{mL})$ QC samples and evaluated by the percentage of calculated ratio from the obtained data after stability testing and at time zero. The freeze-thaw stability was determined over three freeze-thaw cycles within 3 days. In each cycle, spiked plasma samples were frozen at $-80^{\circ} \mathrm{C}$ for $12 \mathrm{~h}$ and thawed at room temperature. The short-term stability was examined by analyzing QC samples kept at room temperature for $6 \mathrm{~h}$ before sample preparation. The long-term stability was evaluated by analyzing QC samples stored at $-80{ }^{\circ} \mathrm{C}$ for 30 days before sample preparation. The results were compared with those obtained from the freshly prepared QC samples. The stability of stock standard solution was investigated after storage at $4{ }^{\circ} \mathrm{C}$ for 7 days. The stability was measured by comparison between the peak area of the derivatized samples prepared with the refrigerated stock standard solution and the samples prepared with fresh stock standard solution. The post-preparative stability was evaluated by keeping prepared QC samples in the autosampler under normal analytical conditions for $24 \mathrm{~h}$ before re-analysis to simulate the time that sample can be in the autosampler. For all stability studies, the acceptance criterion was 85-115\%.

\section{6. Analysis of Patient Samples}

Plasma samples were obtained from 27 patients with epilepsy treated with 50-400 mg of TPM daily. The study was approved by the National Medical Ethics Committee of the Republic of Slovenia and was performed in accordance with the ethical standards laid down in the Declaration of Helsinki. Informed consent was obtained from all patients. Blood samples were collected in EDTA-containing tubes and plasma was obtained after centrifuging at $1500 \times \mathrm{g}$ for $10 \mathrm{~min}$ at $5{ }^{\circ} \mathrm{C}$. The plasma samples were stored at $-80{ }^{\circ} \mathrm{C}$ until analysis. The samples were prepared as described in Sample preparation and derivatization section and subjected to the HPLC-FLD analysis.

\section{Results and Discussion}

\section{1. Optimization of the Analytical Method}

In order to obtain an optimal analytical method, sample preparation, derivatization and chromatography conditions were examined. Liquid/liquid extraction was chosen as a sample preparation procedure based on previous studies which demonstrated that it is the most appro- priate method for TPM extraction from blood samples. ${ }^{23-25}$ Several factors were taken into account to achieve better extraction efficiency. Namely, various extraction solvents (dichloromethane, diethyl ether, ethyl acetate, hexane), extraction solvent $(1.5-5 \mathrm{~mL})$ and plasma (0.5-1 $\mathrm{mL})$ volumes were examined, additionally the effect of mixing time (30-120 s) after the addition of the extraction solvent and slight acidification of plasma with formic acid were tested. The results of the optimization of extraction procedure are presented in Table 1. Dichloromethane had the highest extraction efficiency among all tested extraction solvents. Comparable extraction recovery was obtained with diethyl ether; however, using this solvent precipitation in organic layer was observed in some samples. We were able to significantly reduce the volume of plasma (from 1.0 to $0.5 \mathrm{~mL}$ ) and the volume of organic extraction media (from 5 to $1.5 \mathrm{~mL}$ ) compared to previously developed methods. ${ }^{23-25}$ Variations in the extraction conditions resulted in a simplified extraction procedure which enables faster single-step drying process. Due to a reduction of plasma sample volume the procedure is suitable for TDM in pediatric population. Furthermore, the obtained results indicate a possibility for an additional reduction of the plasma sample volume $(\geq 0.1$ $\mathrm{mL})$.

NBD-Cl was used as a labeling agent for TPM derivatization (Figure 1). Since TPM has no ultraviolet, visible or fluorescence absorption, stable adducts with

Table 1. Optimization of extraction parameters

\begin{tabular}{lc}
\hline Parameter & Extraction recovery $(\%)^{\mathbf{a}}$ \\
\hline Extraction solvent $^{b}$ & 100 \\
DCM & 84 \\
DEE & 12 \\
EA & 0 \\
hexane & 100 \\
DCM:DEE $(1: 1)$ & 78 \\
DCM:EA $(1: 1)$ & 70 \\
DCM:hexane $(1: 1)$ & \\
Extraction solvent volume & 100 \\
$1.5 \mathrm{~mL}$ & 84 \\
$5.0 \mathrm{~mL}$ & \\
Plasma volume & 100 \\
$0.5 \mathrm{~mL}$ & 97 \\
$1.0 \mathrm{~mL}$ & \\
Acidification of plasma & 100 \\
pH $=6.0$ & 100 \\
pH $=7.4$ & \\
Mixing time & 100 \\
$30 \mathrm{~s}$ & 99 \\
$60 \mathrm{~s}$ & 95 \\
$90 \mathrm{~s}$ & 96 \\
$120 \mathrm{~s}$ & \\
&
\end{tabular}

${ }^{\mathrm{a}}$ relative extraction recovery; ${ }^{\mathrm{b}} \mathrm{DCM}$ - dichloromethane, DEE - diethyl ether, EA - ethyl acetate 
A)<smiles>CC1(C)O[C@H]2CO[C@]3(COS(N)(=O)=O)OC(C)(C)O[C@@H]3[C@@H]2O1</smiles>

B)<smiles>NS(=O)(=O)c1cc2c(cc1C(F)(F)F)NC(Cc1ccccc1)NS2(=O)=O</smiles>

C)<smiles>O=[N+]([O-])c1ccc(Cl)c2nonc12</smiles><smiles>[R]S(N)(=O)=O</smiles><smiles>[18OH2]</smiles><smiles>[R]OS(=O)Nc1ccc([N+](=O)[O-])c2nonc12</smiles>

Figure 1: Chemical structures of A) topiramate, B) bendroflumethiazide (IS) and C) derivatization reaction scheme.

NBD-Cl allowed its detection by FLD. As previously reported, TPM reacts with this reagent in an alkaline medium and the derivatization reaction appeared to be highly dependent on $\mathrm{pH}$ of borate buffer, concentration of $\mathrm{NBD}-\mathrm{Cl}$ solution, composition of reaction medium and reaction temperature. ${ }^{25}$ The concentration of NBD-Cl solution $(3-20 \mathrm{mg} / \mathrm{mL}), \mathrm{pH}(10-11)$ and concentration $(0.125-0.5 \mathrm{M})$ of borate buffer, composition (acetonitrile, methanol, dichloromethane) and the final volume (112.5-225 $\mu \mathrm{L})$ of derivatization medium, reaction time (13-17 $\mathrm{min})$ and derivatization reaction temperature $\left(55-65{ }^{\circ} \mathrm{C}\right)$ were systematically varied around the expected optimal values from our preliminary studies. The derivatization with NBD-Cl was optimized at TPM concentration of $3.0 \mu \mathrm{g} / \mathrm{mL}$.

Contrary to the previous report ${ }^{25}$ we have found that dichloromethane is not a suitable medium for derivatization due to its volatility and separation of the media into two immiscible phases after derivatization. The derivatization yield using dichloromethane alone or in combination with other solvents was low (Table 2). Additionally, derivatization was strongly affected by the concentration

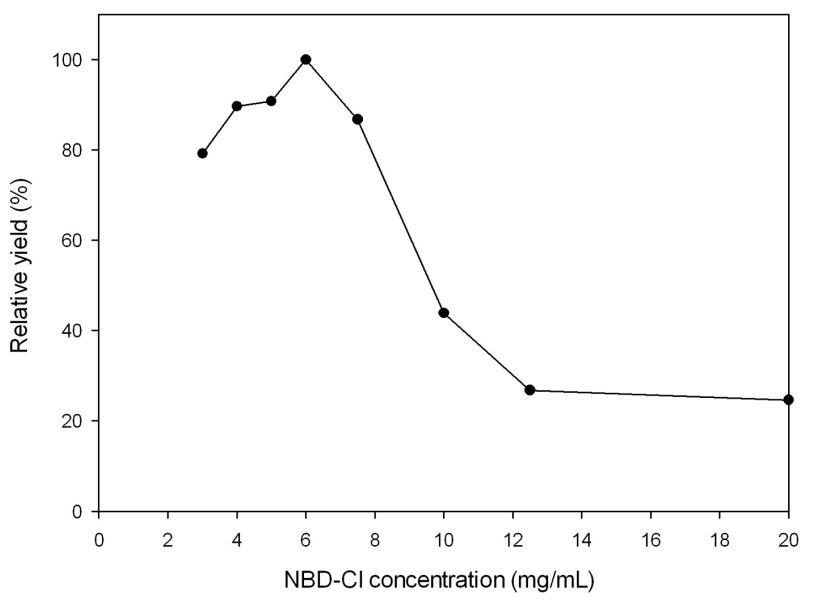

Figure 2. The effect of NBD-Cl concentration on the relative yield of derivatization reaction with TPM.

of the fluorescent labeling agent (Figure 2) and the concentration of the borate buffer. Variations of other parameters had minor effect on derivatization and were within the experimental error (Table 2). The optimal condi- 
tions used for the derivatization are described in the Experimental section.

Selecting an appropriate IS is an essential part of any quantitative analysis. Ideally, IS should be a structural analog with similar physicochemical properties and retention time to the analyte of interest. Moreover, because of the precolumn derivatization step it should reproducibly react with the labeling agent resulting in a stable derivatization product. Different substances were examined as potential IS, including bendroflumethiazide, amlodipine, aminobenzothiazole, amantadine, isoniazide, trimethoprim, procainamide, norvaline and phenylalanine derivatives. Bendroflumethiazide, a compound with a sulfonamide functional group (Figure 1B) was chosen as the most suitable IS according to its similar physicochemical characteristics, ionization and chromatographic elution, as well as comparable recovery to that of TPM.

Table 2. Optimization of derivatization parameters

\begin{tabular}{lc}
\hline Parameter & Derivatization yield (\%) \\
\hline Borate buffer concentration & \\
$0.125 \mathrm{M}$ & 3 \\
$0.25 \mathrm{M}$ & 33 \\
$0.50 \mathrm{M}$ & 100 \\
pH of borate buffer & \\
$\mathrm{pH}=10.0$ & 98 \\
$\mathrm{pH}=10.5$ & 100 \\
$\mathrm{pH}=11.0$ & 97 \\
Derivatization media ${ }^{\mathbf{a}}$ & \\
$\mathrm{ACN}$ & 100 \\
$\mathrm{DCM}$ & 58 \\
$\mathrm{MeOH}$ & 50 \\
$\mathrm{ACN}: \mathrm{DCM}(1: 1)$ & 52 \\
$\mathrm{ACN}: \mathrm{MeOH}(1: 1)$ & 90 \\
DCM:MeOH $(1: 1)$ & 37 \\
DCM:ACN:MeOH $(2: 1: 1)$ & 43 \\
Volume of derivatization media & \\
$0.125 \mathrm{~mL}$ & 97 \\
$0.250 \mathrm{~mL}$ & 100 \\
Derivatization time & \\
$13 \mathrm{~min}$ & 96 \\
$15 \mathrm{~min}$ & 100 \\
$17 \mathrm{~min}$ & 93 \\
Derivatization temperature & 93 \\
$55^{\circ} \mathrm{C}$ & 100 \\
$60{ }^{\circ} \mathrm{C}$ & \\
$65{ }^{\circ} \mathrm{C}$ & \\
\hline
\end{tabular}

${ }^{a}$ relative derivatization yield; ${ }^{\mathrm{b}} \mathrm{ACN}$ - acetonitrile, DCM - dichloromethane, $\mathrm{MeOH}$ - methanol

Several reversed-phase analytical columns, mobile phase compositions (mixtures of methanol or acetonitrile with phosphate buffer at various ratios and $\mathrm{pH}$ ), injection volumes $(5-20 \mu \mathrm{L})$, flow rates $(1.0-1.5 \mathrm{~mL})$ and column temperatures $\left(40-50{ }^{\circ} \mathrm{C}\right)$ were tested to optimize the chro- matographic peak shape, peak width and separation of TPM from endogenous peaks and IS. Optimal separation, symmetric peaks and shorter retention times were obtained on Eclipse plus C18 column when a mixture of potassium phosphate buffer (0.05 M, pH 5.5) and acetonitrile, instead of methanol, was chosen as a mobile phase. Compared to previously reported HPLC methods ${ }^{23-26}$ our method minimizes the consumption of harmful organic solvents by using lower percentage of organic modifier and lower flow rate of the mobile phase. Additionally, in order to obtain maximal signal intensities of the TPM derivative, its excitation and emission spectra were recorded. Overall, chromatography optimization resulted in improved resolution and symmetry of chromatographic peaks under isocratic conditions within a 9-min run time. Retention times of TPM and IS were 4.1 and $7.1 \mathrm{~min}$, respectively (Figure 3C).

\section{2. Method Validation}

\subsection{Selectivity}

Selectivity of the method was confirmed by the analysis of six blank plasma samples from different sources and plasma samples containing the highest therapeutic concentration of several potentially co-administered drugs with TPM, such as gabapentin, pregabalin, lamotrigine, levetiracetam, vigabatrin, carbamazepine, oxcarbazepine, carbamazepine epoxide, licarbazepine, zonisamide, lacosamide, clonazepam, diazepam, fluoxetine, sertraline, desimipramine, propranolol, metoprolol, enalapril, amlodipine, acetaminophen, diclofenac, amoxicillin, ciprofloxacin and ranitidine. All these compounds have a functional amino group, as a requirement for NBD-Cl derivatization and detection using the proposed method. Selectivity study demonstrated that there were no interfering peaks in the blank plasma samples, nor from any of the tested drugs at the retention times of TPM and IS. Only vigabatrin, gabapentin, pregabalin and zonisamide were derivatized with the NBD-Cl and eluted within 20 min runs at 1.2, 2.5, 2.6 and $2.8 \mathrm{~min}$, respectively. Representative chromatograms of a blank plasma sample and plasma sample spiked with TPM at the concentration level of the $\mathrm{QCl}(0.03 \mu \mathrm{g} / \mathrm{mL})$ and IS, are shown in Figure $3 \mathrm{~A}$ and $3 \mathrm{~B}$, respectively. Figure $3 \mathrm{C}$ represents a typical chromatogram of human plasma from a patient treated with TPM $400 \mathrm{mg} /$ day.

\section{2. 2. Accuracy and Precision}

As shown in Table 3, inter-day and intra-day precision were below $8 \%$. Similarly, accuracy was better than $10 \%$ in all cases, which is within the defined acceptance criteria. Additionally, $\mathrm{CV}$ of re-injection reproducibility was less than $0.5 \%(\mathrm{n}=5)$. This demonstrates that an analytical run could be reanalyzed in case of an instrument failure. 

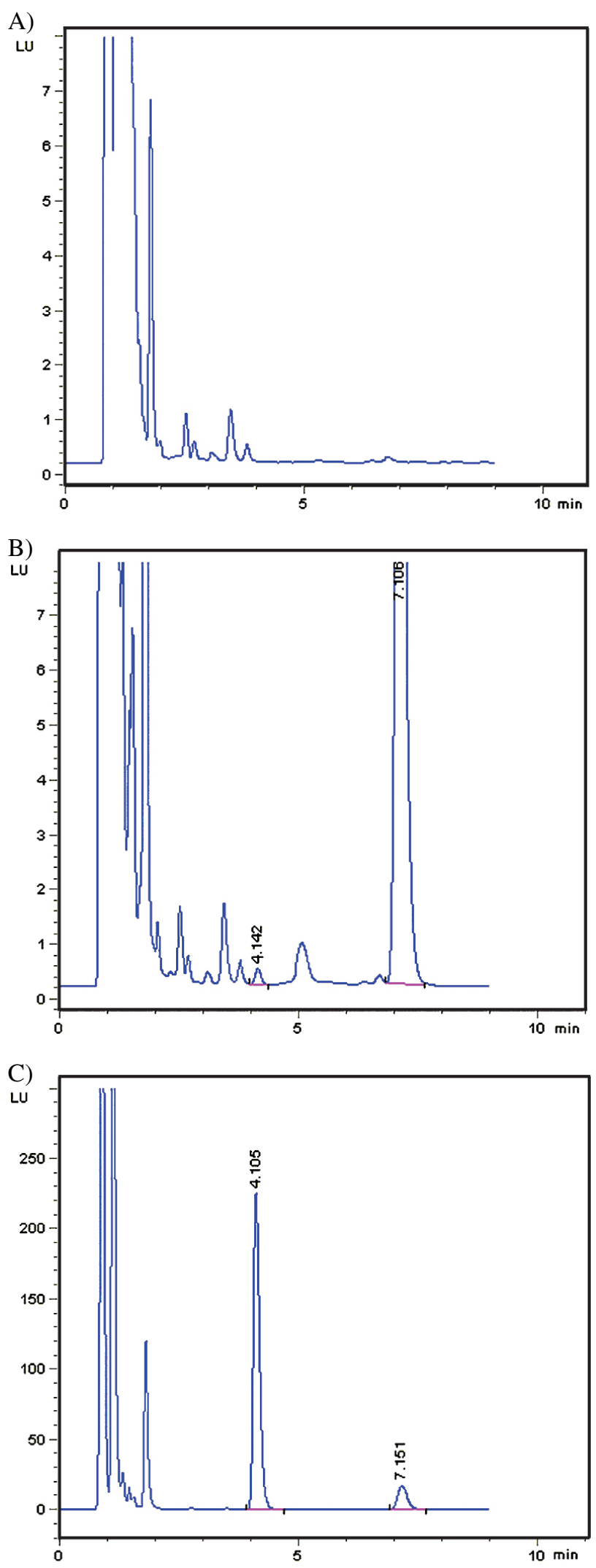

Figure 3. Chromatograms of extracted and derivatized human plasma. A) blank sample; B) plasma sample spiked with TPM at 0.03 $\mu \mathrm{g} / \mathrm{mL}(\mathrm{QCl})$ and $\mathrm{C})$ plasma sample $(9.27 \mu \mathrm{g} / \mathrm{mL})$ from a patient treated with $400 \mathrm{mg}$ TPM/day. Retention time of TPM and IS are 4.1 and $7.1 \mathrm{~min}$, respectively.

\section{2. 3. Linearity}

The assay was verified on three separate days using the calibration standard solutions. The standard calibration curves were linear over the concentration range from

Table 3. Intra- and inter-day precision and accuracy for the determination of TPM in human plasma by HPLC-FLD

\begin{tabular}{lccc}
\hline $\begin{array}{l}\text { Nominal } \\
\text { concentration } \\
(\boldsymbol{\mu g} / \mathbf{m L})\end{array}$ & $\begin{array}{c}{ }^{\mathrm{a}} \text { Concentration } \\
\text { found } \\
(\boldsymbol{\mu g} / \mathbf{m L})\end{array}$ & $\mathbf{C V}(\%)$ & Bias $(\%)$ \\
\hline Intra-day $(\mathrm{n}=5)$ & $0.03 \pm 0.003$ & 7.9 & 9.9 \\
0.03 & $1.53 \pm 0.03$ & 1.7 & 2.0 \\
1.50 & $15.2 \pm 0.3$ & 2.3 & 1.4 \\
15.0 & $0.03 \pm 0.001$ & 2.7 & 10.2 \\
\hline Inter-day $(\mathrm{n}=15)$ & $1.54 \pm 0.03$ & 2.2 & 2.4 \\
0.03 & $15.3 \pm 0.03$ & 0.2 & 1.9 \\
1.50 & & & \\
15.0 &
\end{tabular}

${ }^{\mathrm{a}}$ results are presented as mean $\pm \mathrm{SD}$.

0.01 to $24 \mu \mathrm{g} / \mathrm{mL}$. Linear correlations $\left(\mathrm{r}^{2}>0.9998\right)$ were obtained using weighted linear regression analysis with LLOQ of $0.01 \mu \mathrm{g} / \mathrm{mL}$. Due to wide calibration range (2400 fold) various weighting schemes $\left(1,1 / \mathrm{x}, 1 / \mathrm{x}^{2}, 1 / \mathrm{x}^{1 / 2}\right.$, $\left.1 / \mathrm{y}, 1 / \mathrm{y}^{2}, 1 / \mathrm{y}^{1 / 2}\right)$ were used to avoid biasing the calibration line in favor of the high standards. The best calibration model with $1 / \mathrm{x}^{2}$ as a weighting factor was chosen during validation, taking into account the sums of absolute percentage relative error. ${ }^{39}$

\section{2. 4. Recovery and Stability}

The mean extraction efficiencies of TPM and IS examined at three QC concentrations were $87.3 \pm 3.1 \%$ and $77.6 \pm 1.8 \%$, respectively. Recoveries of TPM and

Table 4. Stability of TPM in stock solution and in human plasma under various storage conditions

\begin{tabular}{lrr}
\hline aStability & \multicolumn{2}{c}{$\begin{array}{c}\text { Analyte concentration } \\
(\boldsymbol{\mu g} / \mathbf{m L})\end{array}$} \\
& $\mathbf{0 . 0 3}$ & \multicolumn{1}{c}{$\mathbf{1 5}$} \\
\hline Freeze and thaw stability (\%) & $102.5 \pm 4.5$ & $99.7 \pm 4.8$ \\
Stock solution stability (\%) & $101.3 \pm 4.1$ & $104.9 \pm 2.3$ \\
Post-preparative stability (\%) & $99.5 \pm 4.9$ & $100.7 \pm 2.3$ \\
Short-term stability (\%) & $93.2 \pm 3.7$ & $97.2 \pm 2.4$ \\
Long-term stability (\%) & $105.5 \pm 2.5$ & $107.3 \pm 1.2$ \\
\hline
\end{tabular}

${ }^{\mathrm{a}}$ results are presented as mean $\pm \mathrm{SD}$.

IS from spiked plasma samples were reproducible. The data of TPM stability at different experimental conditions comprising the storage of processed samples in the autosampler for up to $24 \mathrm{~h}$, freeze-thaw, short-term $(6 \mathrm{~h}$ 
at room temperature) and long-term storage $\left(-80{ }^{\circ} \mathrm{C}\right)$ are presented in Table 4 . The results of the stability evaluation were within the acceptance criteria and allowed us to conclude that no significant loss of TPM was observed during sample preparation and stock solution handling.

\section{3. Clinical Application of the Method}

For various reasons, including insufficient analytical sensitivity $^{12,23,24,26,28,29,31,35}$ and linearity, ${ }^{24,25,32-34,36}$ previously reported liquid chromatography techniques coupled with various detection systems can not accurately determine full therapeutic range of TPM concentrations. These methods either lack adequate sensitivity, and consequently cannot be applied in pharmacokinetic studies, or the method range is to narrow and therefore they are not practical for routine TDM. Furthermore, in recent years there has been a trend of using TPM dosages lower than those tested in the initial clinical trials. Therefore the reference concentration range does not reflect the individual therapeutic range as in most patients TPM concentration is probably lower. ${ }^{5}$

We have applied the method for TDM in patients with epilepsy treated with TPM. A representative chromatogram from one of these patients is shown in Figure 3C, which demonstrates that peak shape and resolution are similar to that obtained using spiked blank plasma (Figure 3B), with no interferences. Trough TPM plasma concentration range determined in 27 patients on stabile TPM therapy $50-400 \mathrm{mg} /$ day, was $0.07-10.9 \mu \mathrm{g} / \mathrm{mL}$, which is in agreement with the earlier reported range. ${ }^{5}$ The relationship between steady-state trough TPM concentration and TPM dose per body weight is demonstrated in Figure 4. Poor correlation $\left(\mathrm{R}^{2}=0.156\right)$ reveals the potential benefit of using TDM in managing patients with epilepsy.

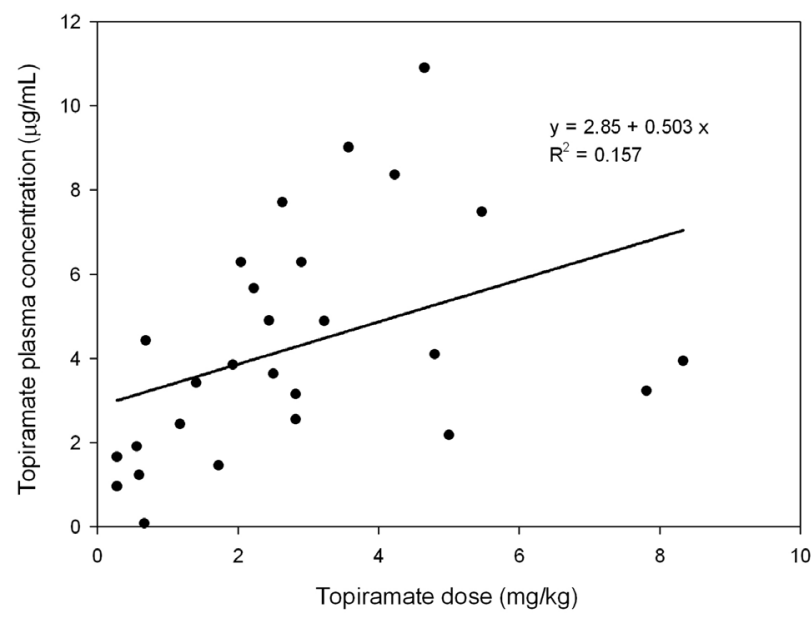

Figure 4: The relationship between steady-state TPM trough concentration and TPM dose per body weight in 27 patients with epilepsy on stabile TPM therapy $50-400 \mathrm{mg} /$ day.
It needs to be emphasized that sensitivity of the present HPLC-FLD method is comparable to the sensitivity of the more sophisticated LC-MS methods, ${ }^{30,32-34,36}$ which makes it appropriate also for pharmacokinetic profiling and bioequivalence assessments of low-dose TPM formulations in healthy volunteers.

\section{Conclusions}

Simple, sensitive, accurate and precise HPLC-FLD method for determination of TPM in human plasma is described. Compared to previously developed methods using derivatization, the main advantage of our method is the simplicity in sample preparation, wider analytical range and comparable sensitivity to the more sophisticated LC-MS/MS methods. The presented method is suitable for routine TDM of TPM in patients with epilepsy as well as for pharmacokinetic and bioequivalence studies. Moreover, small volume of blood plasma used for the analysis along with high sensitivity allows its application in pediatric studies.

\section{Acknowledgments}

This work was supported by the Slovenian Research Agency (ARRS Grant P1-0189) and Ad Futura Scientific and Educational Foundation of the Republic of Slovenia.

\section{References}

1. B. F. Bourgeois, J. Child Neurol. 2000, 15, S27-30. http://dx.doi.org/10.1177/088307380001500106

2. R. P. Shank, B. E. Maryanoff, CNS Neurosci. Ther. 2008, 14, 120-142. http://dx.doi.org/10.1111/j.1527-3458.2008.00041.x

3. M. C. Walker, J. W. A. S Sander, Seizure 1996, 5, 199-203. http://dx.doi.org/10.1016/S1059-1311(96)80036-7

4. R. P. Shank, J. F. Gardocki, A. J. Streeter, B. E. Maryanoff, Epilepsia 2000, 41, S3-S9. http://dx.doi.org/10.1111/j.1528-1157.2000.tb02163.x

5. P. N. Patsalos, D. J. Berry, B. F. Bourgeois, J. C. Cloyd, T. A. Glauser, S. I. Johannessen, I. E. Leppik, T. Tomson, E. Perucca, Epilepsia 2008, 49, 1239-1276. http://dx.doi.org/10.1111/j.1528-1167.2008.01561.x

6. S. I. Johannessen, T. Tomson, Clin. Pharmacokinet. 2006, 45, 1061-1075. http://dx.doi.org/10.2165/00003088-200645110-00002

7. D. Mimrod, T. M. Specchio, M. Britzi, E. Perucca, N. Specchio, A. La Neve, S. Soback, R. H. Levy, G. Gatti, D. R. Doose, B. E. Maryanoff, M. Bialer, Epilepsia 2005, 46, 1046- 1054. http://dx.doi.org/10.1111/j.1528-1167.2005.06805.x

8. M. Britzi, E. Perucca, S. Soback, R. H. Levy, C. Fattore, F. Crema, G. Gatti, D. R. Doose, B. E. Maryanoff, M. Bialer, Epilepsia 2005, 46, 378-384. 
http://dx.doi.org/10.1111/j.0013-9580.2005.55204.x

9. T. Vovk, M.B. Jakovljevic, M. K. Kos, S. M. Jankovic, A. Mrhar, I. Grabnar, Biol. Pharm. Bull. 2010, 33, 1176-1182. http://dx.doi.org/10.1248/bpb.33.1176

10. M. G. Dahlin, I. K. Ohman, Pediatr. Neurol. 2004, 31, 248 253. http://dx.doi.org/10.1016/j.pediatrneurol.2004.04.005

11. N. Zanotta, M. E. Raggi, L. Radice, A. Degrate, N. Bresolin, C. Zucca, Seizure-Eur. J. Epilep. 2006, 15, 86-92.

12. K. M. Matar, Clin. Chim. Acta 2010, 411, 729-734. http://dx.doi.org/10.1016/j.cca.2010.02.003

13. M. D. Krasowski, Pharmaceuticals (Basel) 2010, 3, 19091935. http://dx.doi.org/10.3390/ph3061909

14. E. Perucca, Fund. Clin. Pharmacol. 2002, 16, 249-249. http://dx.doi.org/10.1046/j.1472-8206.2002.00115.x

15. J. Kang, Y. S. Park, S. H. Kim, M. Y. Jun, Korean J. Physiol. Pharmacol. 2011, 15, 67-81. http://dx.doi.org/10.4196/kjpp.2011.15.2.67

16. D. J. Berry, P. N. Patsalos, Ther. Drug Monit. 2000, 22, 460-464. http://dx.doi.org/10.1097/00007691-200008000-00016

17. C. L. H. Snozek, L. A. Rollins, P. W. Peterson, L. J. Langman, Ther. Drug Monit. 2010, 32, 107-111. http://dx.doi.org/10.1097/FTD.0b013e3181c4cebb

18. M. L. Holland, J. A. Uetz, K. T. Ng, J. Chromatogr-Biomed. 1988, 433, 276-281.

19. C. E. Wolf, C. R. Crooks, A. Poklis, J. Anal. Toxicol. 2000, 24, 661-663. http://dx.doi.org/10.1093/jat/24.7.661

20. P. H. Tang, M. V. Miles, T. A. Glauser, L. Coletta, N. Doughman, D. Doose, M. Frey, A. DeGrauw, Ther. Drug Monit. 2000, 22, 195-201. http://dx.doi.org/10.1097/00007691-200004000-00010

21. J. M. Riffitts, L. G. Gisclon, R. J. Stubbs, M. E. Palmer, J. Pharm. Biomed. Anal. 1999, 19, 363-371. http://dx.doi.org/10.1016/S0731-7085(98)00137-X

22. J. Malakova, H. Brozmanova, V. Vorisek, V. Prochazkova, V. Palicka, Chromatographia 2007, 66, 363-367. http://dx.doi.org/10.1365/s10337-007-0310-y

23. G. Bahrami, S. Mirzaeei, B. Mohammadi, A. Kiani, J. Chromatogr. B 2005, 822, 322-325. http://dx.doi.org/10.1016/j.jchromb.2005.05.032

24. G. Bahrami, S. Mirzaeei, A. Kiani, J. Chromatogr. B 2004, 813, 175-180. http://dx.doi.org/10.1016/j.jchromb.2004.09.054

25. G. Bahrami, B. Mohammadi, J. Chromatogr. B 2007, 850, 400-404. http://dx.doi.org/10.1016/j.jchromb.2006.12.016

26. L. Mercolini, R. Mandrioli, M. Amore, M. A. Raggi, J. Pharm. Biomed. Anal. 2010, 53, 62-67. http://dx.doi.org/10.1016/j.jpba.2010.02.036

27. R. Mandrioli, A. Musenga, E. Kenndler, M. De Donno, M. Amore, M. A. Raggi, J. Pharm. Biomed. Anal. 2010, 53, 1319-1323. http://dx.doi.org/10.1016/j.jpba.2010.03.007

28. M. Contin, R. Riva, F. Albani, A. Baruzzi, J. Chromatogr. B 2001, 761, 133-137. http://dx.doi.org/10.1016/S0378-4347(01)00302-4

29. S. Chen, P. M. Carvey, Rapid Commun. Mass Spectrom. 2001, 15, 159-163. http://dx.doi.org/10.1002/1097-0231 (20010130)15:2<159::AID-RCM210>3.0.CO;2-W

30. J. Christensen, C. S. Hojskov, J. H. Poulsen, Ther. Drug Monit. 2002, 24, 658-664. http://dx.doi.org/10.1097/00007691-200210000-00013

31. K. B. Kim, K. A. Seo, S. E. Kim, S. K. Bae, D. H. Kim, J. G. Shin, J. Pharm. Biomed. Anal. 2011, 56, 771-777. http://dx.doi.org/10.1016/j.jpba.2011.07.019

32. S. R. Kuchekar, B. H. Zaware, M. L. Kundlik, J. Sep. Sci. 2010, Dec 17.

33. D. Goswami, A. Kumar, A. H. Khuroo, T. Monif, S. Rab, Biomed. Chromatogr. 2009, 23, 1227-1241. http://dx.doi.org/10.1002/bmc.1273

34. J. H. Park, Y. S. Park, M. H. Lee, S. Rhirn, J. C. Song, S. J. Lee, J. M. Kim, L. M. Shaw, J. S. Kang, Biomed. Chromatogr. 2008, 22, 822-829. http://dx.doi.org/10.1002/bmc.995

35. M. Shibata, S. Hashi, H. Nakanishi, S. Masuda, T. Katsura, I. Yano, Biomed. Chromatogr. 2012, 26, 1519-1528. http://dx.doi.org/10.1002/bmc.2726

36. T. V. Popov, L. C. Maricic, H. Prosen, D. B. Voncina, Acta Chim. Slov. 2013, 60, 144-150.

37. D. F. Chollet, J. Chromatogr. B 2002, 767, 191-233. http://dx.doi.org/10.1016/S0378-4347(01)00502-3

38. FDA. Guidance for industry: Bioanalytical method validation, US Department of Health and Human Services, FDA, CDER and CVM: Washington, DC, 2001.

39. A. M. Almeida, M. M. Castel-Branco, A. C. Falcao, J. Chromatogr. B 2002, 774, 215-222.

http://dx.doi.org/10.1016/S1570-0232(02)00244-1

\section{Povzetek}

Razvili in validirali smo analizno metodo, ki temelji na tekočinski kromatografiji visoke ločljivosti s fluorescenčno detekcijo in omogoča rutinsko terapevtsko spremljanje plazemskih koncentracij protiepileptičnega zdravila topiramata pri bolnikih z epilepsijo. Koncentracijo topiramata v plazmi smo določali po predkolonski derivatizaciji, z uporabo 4-kloro-7-nitrobenzofurazana kot fluorescenčnega reagenta za označevanje in bendroflumetiazida kot internega standarda. Metoda je enostavna, občutljiva, zanesljiva, ponovljiva, selektivna in ima območje linearnosti pri koncentracijah od 0,01 do $24 \mu \mathrm{g} / \mathrm{mL}\left(\mathrm{r}^{2}>0.9998\right)$. Znotraj dnevna točnost, izražena kot odstopanje od prave vrednosti, je od 1,4 do 9,9\%, meddnevna pa od 1,9 do $10,2 \%$. Znotraj dnevna in meddnevna natačnost metode, izraženi kot relativni standardni odklon, pa sta boljši od 7,9 oziroma 2,7 \%. Validirano metodo smo uporabili za merjenje plazemskih koncentracij topiramata pri bolnikih z epilepsijo, s čimer smo potrdili njeno primernost za terapevtsko spremljanje topiramata. Poleg tega je metoda uporabna tudi za določanje topiramata $v$ farmakokinetičnih in bioekvivalenčnih študijah. 